\title{
Taking the Problem Seriously?: Sentencing Indigenous and Non-Indigenous Domestic Violence Offenders
}

\author{
Samantha Jeffries \\ School of Criminology and Criminal Justice \\ Griffith University, QLD, 4122, Australia \\ Ph:+61-7-3735-1120; e-mail: s.jeffries@griffith.edu.au \\ Christine E.W. Bond \\ Griffith University \\ School of Criminology and Criminal Justice \\ Griffith University, QLD, 4222, Australia \\ Ph:+61-7-5552-7040; e-mail: c.bond@griffith.edu.au
}

\begin{abstract}
The 'problem' of Indigenous domestic violence has become increasingly dominant in populist and government discourse, with the criminal justice system (including the courts) being criticised for the possible lenient treatment of offenders. Using a population of cases sentenced in New South Wales from January 2009 to June 2012, this paper uses multivariate analyses to explore the intersection between Indigenous status, context of violence (domestic versus non-domestic) and the imprisonment sentencing decision. Results suggest that when sentenced under comparable statistical circumstances, Indigenous domestic violence offenders are equally likely as those convicted of violent crimes outside of intimate/familial contexts to be sentenced to prison. In contrast, non-Indigenous domestic violence offenders
\end{abstract}


are significantly less likely than those convicted of violent offences outside of intimate/familial relationships contexts to be sentenced to prison. Drawing on the focal concerns sentencing perspective, possible explanations for this finding are explored. The tension faced by the courts between the impact of colonialism on Indigenous offenders and their communities, the need to protect Indigenous victims of domestic violence and their communities, as well as overarching expectations around the punitive treatment of crimes of domestic violence are discussed.

Key words: domestic violence, sentencing, Indigenous Australians. 


\section{Introduction}

In the last few decades, there have been significant shifts in criminal justice policy and practice in responding to the violence perpetrated against intimates and family members in Australia. Examples of these changes include the implementation of pro-arrest policies and the introduction of legislation that criminalises non-physical forms of domestic violence ${ }^{1}$ such as harassment and stalking (Ogilvie, 2000). Legislative definitions of what constitutes domestic violence have also broadened to include criminal behaviour that would not be considered violent outside of intimate and familial relationship contexts (e.g. property damage, offensive behaviour) (Ringland and Fitzgerald, 2010).

At the same time, the 'problem' of Indigenous domestic violence has become increasingly dominant in populist and government discourse; a problem that is presented as both illustrative of, as well as contributing to, community dysfunction. Since the late 1990s, a number of Australian government taskforces have reported on the 'endemic' nature of this violence. $^{2}$ The criminal justice system response to Indigenous domestic violence has also been critiqued, especially the possible 'lenient' treatment of Indigenous male perpetrators (Northern Territory Government, 2007; New South Wales Attorney General’s Department, 2006; State of Victoria, 2003; Gordon, Hallahan and Henry, 2002; Pugh, 2002; State of Queensland, 1999). Cases of apparent leniency in the sentencing of Indigenous male offenders convicted of violence often attract media attention suggesting that this type of violence is not being taken seriously by Australian criminal justice agencies (most recently, see ABC News, 2013; McGlade, 2013; Robinson, 2013). However, much of the concern

\footnotetext{
${ }^{1}$ For ease of readability, we will use the term domestic violence, although it should be read as including family violence.

${ }^{2}$ Overwhelmingly, domestic violence is intra-racial with most victims of Indigenous violence being Indigenous and most victims of non-Indigenous violence being non-Indigenous (Jarrett, 2013: 257).
} 
about the lenient treatment of Indigenous domestic violence is based on specific cases or incidents.

The apparent leniency afforded to Indigenous domestic violence offenders raised by particular cases is not surprising given expectations after the Royal Commission into Aboriginal Deaths in Custody (1991). The Royal Commission became a trigger for sensitising Australian courts to the marginalised position of Indigenous Australians, highlighting the importance of cultural considerations, Indigenous involvement in sentencing and the negative consequences of incarceration on individual offenders, families and communities (Jeffries and Bond, 2009). The Commission argued that "the powers and decisions of sentencing courts present considerable opportunity for reducing the numbers of Aboriginal people in custody” (Royal Commission into Aboriginal Deaths in Custody 1991, Chapter 2).

In the post-Royal Commission environment, the sentence severity of Indigenous domestic violence offenders may be influenced by judicial acceptance of customary law misinterpretations (supposedly condoning violence), consideration of Indigenous disadvantage, community dysfunction and the detrimental impact of incarceration on Indigenous offenders, families and communities (Jarrett, 2013; Douglas and Corrin 2010; Blagg, 2008: 173; Cripps, Davis and Taylor, 2008; Douglas, 2005; Cunneen, 1992; Bolger, 1991: 80-84; Payne, 199; Atkinson, 1990). As Marchetti (2011: 27) notes, such considerations by the courts, predominately for Indigenous male offenders, are an attempt to recognise the devastating effects of colonisation, but leave little room for considering the problems facing Indigenous women and children who are so often the victims of the men's violence. 
Recent case law and legislative change to sentencing in the Northern Territory suggest victim protection may well be taking primacy over concerns about over-representation in incarceration and cultural considerations. In the aftermath of the Northern Territory’s Board of Inquiry into the Protection of Aboriginal Children against Sexual Abuse, the Federal Government enacted the National Emergency Response Act 2007 (NT) which prevents the courts from "taking into account any form of customary law or cultural practice as a reason for excusing, justifying, authorising, requiring or lessening the seriousness of criminal behaviour” (Anthony, 2010: 2). Recent case law in Western Australia, Northern Territory and New South Wales also suggests that the mitigating weight given to Indigenous disadvantage, community dysfunction, over-representation (and its associated negative impacts) maybe lessening, particularly in (although not limited to) domestic violence cases. These changes indicate that the sentencing goals of deterrence, denunciation, Indigenous victim and community protection are now prioritised, with the potential consequence of more punitive sanctioning (Anthony, 2013; Anthony, 2010; Southwood, 2007).

Thus, it is timely to explore whether Australian courts sentence domestic violence cases differently for Indigenous and non-Indigenous offenders. Using case-level data for a population of cases in New South Wales, this study examines the intersection between Indigenous status, the context of violence (domestic versus non-domestic) and the imprisonment (in/out) sentencing outcome.

\section{Prior Research on Sentencing, Domestic Violence and Indigeneity}


A review of the past research shows limited prior empirical examinations of sentencing in cases of domestic violence, but a more extensive body of work exploring the relationship between Indigeneity and sentencing. In other words, with one recent exception, there are no prior examinations of the relationship between Indigeneity, domestic violence and sentencing outcomes.

\section{Sentencing of Domestic Violence Offenders}

Many domestic violence activists and researchers have argued that domestic violence perpetrators should receive the same punishment as other violent offenders, so that it is clearly communicated to perpetrators, victims and the broader community that this type of violence is as serious as non-domestic violence (Olson and Stanlans, 2001). Comparative sentencing analyses of domestic versus non-domestic violence offending are sparse (and even

more so in Australia). However, despite this advocacy, results suggest that crimes against intimates and family members are sentenced less harshly than those involving non-intimate or familial victims (Bond and Jeffries, 2014; Du Mont, Parnis and Forte, 2006; Dawson, 2004; Gannon and Brzozowski, 2004; Cretney and Davis, 1997).

The majority of prior research on the decision to imprison has relied on bivariate analyses which fail to adjust for other known sentencing factors (see Du Mont, Parnis and Forte, 2006; Gannon and Brzozowski 2004; Cretney and Davis, 1997). In a more recent and robust Australian study, Bond and Jeffries’ (2014) multivariate analysis of the in/out sentencing decision showed that when violent offenders are sentenced in the New South Wales lower courts under statistically similar circumstances (i.e. comparable offender, legal and case characteristics), intimate and familial offenders were less likely to be imprisoned, compared to other types of violent offenders. Interestingly, Indigenous violent offenders were more 
likely to be sentenced to prison than similarly situated non-Indigenous defendants. However, although this tells us that Indigeneity has a direct effect in the sentencing of violent offences, we do not know how Indigenous status interacts with the context of violence (i.e. domestic vs. non-domestic) to impact judicial sanctioning.

\section{Sentencing of Indigenous Peoples in Australia}

There is a now growing body of multivariate statistical analyses in Australia on Indigeneity and sentencing outcomes in the mainstream courts (both higher and lower), problem solving courts and Indigenous courts. Overall, there is strong evidence of parity (and leniency in one jurisdiction, South Australia) in the likelihood of a prison sentence in the higher criminal courts, as well as evidence that there is a lower likelihood of imprisonment for Indigenous defendants in the problem-solving and Indigenous courts (Jeffries and Bond, 2013; Bond and Jeffries, 2012a; Bond and Jeffries, 2012b, Bond and Jeffries, 2011; Jeffries and Bond, 2009; Snowball and Weatherburn, 2007). However, in the conventional lower courts, research suggests that Indigenous offenders may be more likely to receive a prison sentence compared to similarly situated non-Indigenous offenders (Jeffries and Bond, 2011; Jeffries and Bond, 2012, Bond and Jeffries, 2012b).

Beyond suggesting the Indigeneity matters to sentencing decision making, this prior research does not consider how Indigenous status intersects with offence types/contexts to affect sentencing (although Bond and Jeffries, 2011 examined the interaction of Indigenous status and gender). Rather the purpose of these prior studies has been to establish whether or not Indigeneity had an impact on sentencing between court contexts (i.e. mainstream vs. Indigenous court) or within specific court environments (i.e. mainstream and problem solving courts), once other crucial sentencing factors (including offence type) were controlled. 


\section{Sentencing, Domestic Violence, Indigeneity and the Focal Concerns Perspective}

The dominant approach to explaining sentencing disparities has been the focal concerns perspective, which argues that the sentencing decision is governed by judicial assessments of three key matters: blameworthiness and harm; risk (or community protection); and practical constraints and consequences (Johnson, 2003; Steffensmeier, Ulmer and Kramer, 1998). Traditionally, this perspective has been used to explain sentencing disparities based on offender-level characteristics (e.g. gender, Indigeneity). Nonetheless, victim-offender relationships (such as intimate/familial vs. non-intimate/familial) could impact judicial evaluations of blame, risk and practical consequences.

\section{Blameworthiness and Harm}

The first focal concern of blameworthiness and harm centres on judicial assessments of offender culpability and the harmful impacts of his or her offending (Steffensmeier, Ulmer and Kramer, 1998). The seriousness of an offender's crime and criminal history are vital to judicial appraisals of blameworthiness and harm (Mitchell, 2005; Johnson, 2003), but offender-level characteristics (such as Indigeneity and victim-offender relationships) may also impact judicial assessments of blame.

Prior international research, for example, suggests that judges have a tendency to minimise the severity of violence committed within intimate/familial contexts (Gilchrist and Blisset 2002). Non-domestic violence may be perceived as more serious and more harming, because it impacts on the community at large, not just an individual victim (Fradella and Fischer, 2010; Hessick, 2007; Hartman and Belknap, 2003; Gilchrist and Blisset 2002; McCormick et al., 1998). If the perception of domestic violence as a private matter between two parties 
(rather than a public concern) still prevails, we might expect that domestic violence offenders would be perceived as less harmful, and thus the possibility of sentencing leniency being extended to them would increase.

However, the perception of domestic violence as a private matter may not apply to all offender groups. Although non-Indigenous domestic violence may remain 'behind closed doors', the so-called 'epidemic' of this violence in Indigenous Australian communities has been thrust into the public domain. Indigenous domestic violence has been constructed as a public problem demanding taskforces, reports and, in the case of the Northern Territory, decisive government intervention. The harm caused by domestic violence in Indigenous communities is well accepted and, as illustrated by recent sentencing precedence, judicial assessments of harm may be different.

Similarly, there may also be differences in judicial assessments of offender blameworthiness for Indigenous and non-Indigenous domestic violence offenders. For example, assumptions around provocation or victim fault in cases of domestic violence may act to reduce assessments of offender culpability. Research on judicial attitudes to intimate partner violence suggests that the judiciary may assume the presence of victim provocation, or at least see both victim and offender as equally responsible for the behaviour (Ptacek, 1999; Busch, Robertson and Lapsley, 1995). Potentially, this victim blaming tendency may be more pronounced in cases of Indigenous intimate partner violence, where the line between victim and offender may appear blurred as Indigenous women often retaliate violently against their male abusers (Blagg, 2008).

\section{Risk (Community Protection)}


The focal concern of risk (or community protection) involves judicial predictions of the potential future threat posed by offenders to the community (Steffensmeier, Ulmer and Kramer, 1998). Like blameworthiness and harm, judicial officers make predictions about risk using factors such as current crime seriousness and criminal history. Perceptions of future risk are also likely impacted by offence contexts. Domestic violence offenders could be perceived as less threatening in the future to the broader community than non-domestic violence offenders. This is tied, in part, to the emotional triggers often attributed to violence particularly in intimate partner contexts (e.g. offender anger possibly contributed to by victims) which suggests minimal danger to those outside of the relationship (Hessick, 2007; Albonetti, 1991). Sentence severity is often mitigated for those who are perceived as posing minimal future risk to the community at large.

Nonetheless, as with the focal concern of blameworthiness, assessments of risk may plausibly differ by Indigenous status. For example, given current concerns about the broader consequences of domestic violence to Indigenous communities as a whole (i.e. dysfunction), threat is perhaps more likely to be construed beyond the narrow confines of the immediate victim/offender relationship.

\section{Practical Constraints and Consequences}

The final focal concern of practical constraints and consequences recognises that in making sentencing determinations, courts have to take into account a range of practical issues, including: (1) organisational constraints, such as the need to ensure a regular case flow through the court (e.g. entering a guilty plea may reduce sentence severity because it speeds up the process); (2) the social costs of sentencing on the offender's familial relationships; (3) 
societal expectations that may impact the court's general societal standing (Steffensmeier, Ulmer and Kramer, 1998; see also Steffensmeier and Demuth, 2001).

Social costs and societal expectations may be particularly important in understanding the sentencing of domestic compared to non-domestic violence offenders. For example, in domestic violence cases, the social costs of incarcerating the offender may include the economic hardship that will befall the victim(s) through the potential loss of the major 'breadwinner' during incarceration, concern about further damaging victim-offender relationships and the fragmentation of broader familial ties especially parent-child bonds (Hessick, 2007: 386-387; Hartman and Belknap, 2003). These social costs could be especially pertinent to the sentencing Indigenous offenders given the known negative impacts of historical child removal policies (Commonwealth of Australia, 1997; Royal Commission into Aboriginal Deaths in Custody, 1991). However, in the continuing climate of alarm about Indigenous domestic violence, the societal expectation around treating these types of crimes as serious with harmful consequences places courts in a difficult position of keeping Indigenous families together while protecting victims and their communities.

\section{Current Study}

Thus, there are gaps in our empirical understanding of the sentencing of domestic violence offenders, and in particular, the sentencing of Indigenous domestic violence offenders. Theoretically from the focal concerns approach, we might anticipate that Indigenous domestic violence offenders may be sentenced differently to non-Indigenous domestic violence offenders. The contexts of Indigenous and non-Indigenous domestic violence mean that judges and magistrates may have quite different concerns in the sentencing of Indigenous domestic violence cases. The enduring political and policy concerns about domestic violence 
in Indigenous communities over the last two decades may contribute to Indigenous cases involving domestic violence (compared to other types of violence) being assessed as more blameworthy and risky, due in part to the public, endemic and dysfunctional construction of the problem. Yet, the potential fragmentation of familial and community relationships may weigh more heavily in Indigenous domestic violence cases as a social cost that could mitigate sentencing outcomes. Consequently, we focus on two key research questions:

(1) What is the impact of the context of violence on the decision to imprison for Indigenous violent offenders sentenced under comparable statistical circumstances (i.e. with similar demographics, plea, current and prior criminality)?

(2) Does Indigenous status interact with the context of violence in predicting the decision to imprison when offenders are sentenced under comparable statistical circumstances (i.e. with similar demographics, plea, current and prior criminality)?

\section{Data source}

Our study uses adult lower court data from New South Wales from January 2009 to June 2012. The data was obtained from the New South Wales Bureau of Crime Statistics and Research (BOSCAR) Reoffending Database (ROD). New South Wales provides us with a unique site to examine the sentencing of domestic violence offenders, due to the introduction of specific domestic violence offences. Since March 2008, if satisfied that the offence resulted from an incidence of domestic violence, the court is to direct that an offender's conviction be recorded as a domestic violence offence (s.12 Crimes (Domestic and Personal Violence) Act 2007 (NSW)). ${ }^{3}$ There are over 100 domestic violence forms of personal, and

\footnotetext{
${ }^{3}$ The purpose of the legislative reform is to increase the protection of victims of domestic violence, through for instance, "automatic" apprehended domestic violence orders (unless the court is satisfied the order is "not required": s.39 Crimes (Domestic and Personal Violence) Act 2007 (NSW)). The legislation also allows for the ready identification of habitual domestic violence offenders. This recording of domestic violence convictions
} 
some property crime (such as property crimes) now available (Ringland and Fitzgerald, 2010). To have a conviction recorded as a domestic violence offence, an intimate or familial relationship needs to exist between the victim and offender (see s.5 Crimes (Domestic and Personal Violence) Act 2007 (NSW)). Thus, in this study, “domestic” relationship includes both intimates and family members.

\section{Sample}

Our sample includes all adult offenders convicted of a personal offence (including domestic violence offences) as their principal offence (or most serious proven offence) ${ }^{4}$ in the New South Wales Local Courts from January 2009 to June 2012. Our study period commences in January 2009 to allow sufficient time for cases to be finalised after the option to record specific domestic violence offences became available in March 2008.

In total, there were 64,638 cases in which an offender was convicted of a personal or domestic violence offence as their principal offence. Due to missing data primarily on mode of conviction and Indigenous status, 5,974 cases (9.24\%) were excluded from the analyses, leaving an analytic sample of 58,664 cases. $^{5}$ These cases predominately involved non-

will have implications for other criminal justice decision-making. For instance, police are obliged to make applications for apprehended domestic violence orders where there is a prior conviction for domestic violence (ss.27 \& 49 Crimes (Domestic and Personal Violence) Act 2007 (NSW)).

${ }^{4}$ Principal (or most serious) offence is defined as the charged offence receiving the most serious penalty. For further details, see New South Wales Bureau of Crime Statistics and Research (2009, pp.121, 132).

${ }^{5}$ The proportion of missing data for mode of conviction (whether it went to trial or not) was $4.93 \%$ of cases $(2,891)$ and for Indigenous status $8.62 \%(5,574)$. The proportion missing mode of conviction was slightly, although significantly $(\mathrm{p}<0.001)$, higher for Indigenous cases $(5.60 \%)$, compared to non-Indigenous cases $(4.77 \%)$. We estimated our multivariate models with a dummy for missing on mode of conviction; its impact was not significant, and did not change the pattern of effects and significance for the other variables in this model. Those cases missing Indigenous status can be characterised as low level offenders, with fewer multiple convictions, lower mean offence seriousness score, and less extensive prior criminal history. These offenders were released pre-trial (99.5\%), did not have a domestic violence offence recorded (96.2\%), and did not receive a prison sentence (99.3\%). We estimated a direct effects model using the full sample: the dummy variable indicating missing on Indigenous status was not significant. Missing data was not a concern for the other independent variables used in our analysis. There was no missing data on prior criminal history, current offence seriousness, presence of multiple convictions, or domestic violence offence. Less than $1 \%$ of cases were missing data on offender's sex $(0.03 \%)$, age $(0.03 \%)$ and release pre-trial $(0.62 \%)$. 
Indigenous offenders (80.96\%) and male offenders (82.07\%). The average age of all offenders was 33.35 years. Over a quarter of cases (29.27\%) involved a domestic violencerelated principal offence, the majority of which were a conviction for common assault (61.81\% of domestic violent-related offences). A sentence of incarceration was imposed in $11.18 \%$ of cases.

\section{Independent Variables}

Our analyses include measures that are standard in sentencing research, which can be grouped into two categories: offender social characteristics; and legal and case characteristics (see Table 1 for a description of their coding).

[Insert Table 1 about here]

In the first group, offender social characteristics, we include age of offender, sex of the offender and Indigenous status. Indigenous status is based on self-identification by the defendant (a key reason for “unknown” or “missing” values (8.62\%) on Indigenous status).

The second group consists of legal and case characteristics. To capture criminal history, we use a three-category ordinal measure of all prior proven criminal court appearance in the last 10 years from the current case. ${ }^{6}$ We also include two measures of the seriousness of the current offending. The first, the seriousness of the principal offence, is captured by an index, based on actual and prescribed penalties developed by the Australian Bureau of Statistics (2009). This index, known, as the National Offence Index, ranks all offences in order of seriousness from 1 to 155 , with 1 as being the most serious and 155 being the least serious.

\footnotetext{
${ }^{6}$ Not surprisingly, the count of prior proven criminal court appearances is positively skewed (4.926) and highly leptokurtic (104.074), ranging from 0 prior appearances to 122 prior appearances in the last 10 years from the current case.
} 
To assist in the readability of the findings, this index was reverse-coded, so that higher values reflect more serious offences. The second measure of the seriousness of the current offending is a dummy variable that indicates whether the offender had multiple conviction counts for any type of offence. Finally, two dichotomous case processing measures were included. Mode of conviction (i.e. whether the offender went to trial) and offender's pre-trial detention status (whether the offender was out of custody at the time of sentencing). There was just under 5 per cent $(n=3,180)$ of cases with unknown mode of conviction, so we include a missing dummy in our models so that these cases can be retained without biasing the estimated coefficients for the variables of interest. These types of measures are typical in sentencing research regardless of jurisdiction (e.g. Jeffries and Bond, 2009; Jeffries, Fletcher and Newbold, 2003; Johnson, 2003; Steffensmeier, Ulmer and Kramer, 1998).

The final case characteristic in our models is whether the offender was convicted of a domestic violence-related offence (which captures both the intimate or familial context of the offending as well as the intimate or familial relationship between victim and offender). This was measured as a dichotomous variable, with ' 1 ' indicating that the principle offence was recorded as a domestic violence offence, and '0' any other personal (violent) offence.

\section{Dependent Variable}

In our analyses, the imprisonment decision was measured dichotomously (1=prison sentence for the principal offence; 0 =any non-prison sentence). (Suspended prison sentences were coded as a non-custodial option, as offenders are not detained in custodial institutions.)

\section{Analytic Issues}


As is standard in sentencing research, we model the imprisonment decision using a logit model. Two separate models for Indigenous and non-Indigenous cases were estimated. Robust standard errors were calculated and reported, as there were repeat appearances of the same defendants in our data. We also considered the issue of clustering of cases by court location. As many cases will have been heard in the same court locations, there may be correlated error, which leads to the underestimation of standard errors and the corresponding impact on our significance tests. For the purposes of our analysis, the important issue was whether the pattern of results would change if we adjusted for the clustering effect of court location. Thus, we used two different strategies to account for the clustering by court location. The first was to calculate robust standard errors based on court location; the second was to estimate the models with a series of dummy variables for court location (i.e. controls for between-group effects). In both cases, the direction of the estimated coefficients and the pattern of significance remained unchanged, and the magnitude of the unstandardized coefficients was similar. The pattern of significance for differences in the estimate parameters between the Indigenous and non-Indigenous models also remained the same. Consequently, as the estimated effects in our models remain largely unchanged, we report the models without adjusting for court location. However, as the between-group model showed that there were some significant differences between court locations, an in-depth examination- that is beyond the scope of this paper—of how location matters is needed. ${ }^{7}$

A final point to note is that we do not include a correction for selection bias in our model. There are two reasons for this. First, as is the case for almost all sentencing research on the

\footnotetext{
${ }^{7}$ The issue about whether there are systematic differences between urban and remote magistrates' courts, due to fewer alternative sentencing options in some locations, is critical to our increased understanding of the sentencing of offenders, especially Indigenous offenders who are disproportionately living in remote locations (for discussion of this, see Jeffries and Bond, 2011). Although court location has received considerable attention in U.S. sentencing research, Australian research on this point has been sparse. We are currently exploring this issue in another paper under preparation.
} 
imprisonment decision, we do not have data on the preceding decision stage (i.e. conviction) in order to estimate the likelihood of being convicted, and thus, present in our population of convicted cases. Second, the inclusion of a hazard terms (controlling for the likelihood of being in the population being sentenced) has become the most common approach to correcting for selection. Recent work suggests that sentencing research generally has not been able to estimate appropriate and robust selection models, due to the inability to find predictors in the selection model that are not in the substantive model (Bushway, Johnson and Slocum, 2007). Inappropriately corrected estimates may well be more inaccurate than uncorrected estimates (Bushway, Johnson and Slocum, 2007). As a result, we present the uncorrected results (for a similar position, see e.g. Franklin and Fearn, 2012). ${ }^{8}$

\section{Findings}

Table 2 reports the bivariate differences between Indigenous and non-Indigenous cases of violence. Indigenous cases of violence differ significantly from non-Indigenous cases of violence on all characteristics except mode of conviction (where similar proportions of cases went to trial: $13.2 \%$ (Indigenous) vs 13.6\% (non-Indigenous, n.s.). Compared to nonIndigenous violence cases, Indigenous offenders convicted of violence are on average younger (33.8 vs 31.4 years, $\mathrm{p}<0.001$ ), more likely to be female ( $16.4 \%$ vs $24.4 \%, \mathrm{p}<0.001$ ), and less likely to have been released pre-trial (92.1\% vs $74.3 \%, \mathrm{p}<0.001)$. Indigenous cases of violence are also on average more serious, with higher mean seriousness scores (128.3 vs 127.5, $\mathrm{p}<0.001$ ), a greater proportion with multiple conviction counts ( $44.3 \%$ vs $59.3 \%$, $\mathrm{p}<0.001$ ), and higher median prior proven appearances (2 vs 5, $\mathrm{p}<0.001$ ). However, Indigenous cases of violence had a lower proportion of convictions for a domestic violent-

\footnotetext{
${ }^{8}$ Standard diagnostics indicated that multicollinearity was not a problem, with all variance inflation factors within acceptable limits. As these diagnostics are about the relationship between the independent variables (and not the relationship with the dependent variable), the use of tolerance or variance inflation factors are considered appropriate although we will be estimating a logit model (Menard, 2002).
} 
specific offence for the most serious offence compared to non-Indigenous cases of violence (27.8\% vs 29.6\%, $\mathrm{p}<0.001)$. Indigenous cases of violence had a higher proportion of imprisonment orders compared to non-Indigenous cases (25.6\% vs $7.7 \%, \mathrm{p}<0.001)$. This suggests that Indigenous cases of violent offending may be sentenced differently compared to non-Indigenous cases of violent offender.

To examine whether Indigenous and non-Indigenous offenders experience different processes of sentencing for domestic versus non-domestic violence, we estimate Indigenous-specific models of the imprisonment sentencing outcome (see Table 3). This allows us to explore both within as well as between group effects for Indigenous status.

[Insert Table 3 about here]

\section{Direct effect of the context of violence on the decision to imprison for Indigenous and non-}

\section{Indigenous cases of violence}

The results of the Indigenous-specific logit models of the decision to imprison are presented in Table 3. The models fit reasonably well (Indigenous model: pseudo $\mathrm{R}^{2}=0.49$; area under the ROC curve=0.92; non-Indigenous model: pseudo $\mathrm{R}^{2}=0.47$; area under the $\mathrm{ROC}$ curve=0.92). Both models correctly classify over $89 \%$ of cases (Indigenous model: $89.75 \%$; non-Indigenous model: 95.22\%). Table 3 shows several offender, legal and case characteristics have an independent and significant effect on the likelihood of a sentence of imprisonment for both Indigenous and non-Indigenous cases.

For Indigenous cases of violence, being female reduced the odds of imprisonment $(0.453$ times as likely as odds for male offenders), but age had a small but insignificant impact on 
the odds of imprisonment. Not surprisingly, cases with more extensive past and more serious current offending have an increased likelihood of incarceration. For instance, having 5 or more prior proven appearances increased the odds of imprisonment for Indigenous cases of violence (4.899 times as likely as those with 0 to 1 prior appearances). The case processing factors had a direct effect on the likelihood of imprisonment for Indigenous cases of violence. Being released pre-trial substantially and significantly reduces the odds of imprisonment (compared to those who remained in pre-trial custody). Cases that went to trial, versus those that did not, increased the likelihood of imprisonment.

Of most interest is the impact of being convicted of a domestic violence offence. Indigenous cases where the principal offence was domestic violence-related did not have a meaningful or significant impact on the odds of imprisonment. Compared to non-domestic violence offences, domestic violence cases had equal odds of receiving an imprisonment order (O.R. $=0.963$, n.s.).

Like the Indigenous model, the likelihood of an imprisonment order in non-Indigenous cases of violence was influenced by a similar set of offender, legal and case characteristics. Being female and released pre-trial substantively and significantly reduced the odds of imprisonment, while the seriousness of past and current criminality significantly increased the odds of imprisonment. However, for Indigenous cases of violence, age significantly increased the odds of imprisonment, but the magnitude of the effect was small (1.005 increase in the odds for each year). Importantly, the impact of being convicted of a domestic violence offence as the principal offence (compared to violence committed in non-domestic contexts) was substantive and significant. For non-Indigenous cases of violence, being 
convicted of domestic violence decreased the odds of imprisonment (0.624 times as likely as cases of violence committed in non-domestic contexts).

\section{Interactive effect of the context of violence and Indigeneity on the decision to imprison}

Finally, given the focus of our study, the between group differences are of particular interest. These are reported in Table 3, with the shaded boxes indicating the effects that were statistically significantly different $($ at $\mathrm{p}<0.05$ ) between the Indigenous and non-Indigenous models. These results suggest that, overall, Indigenous and non-Indigenous cases of violence experience a similar sentencing process, with few significant between group differences in the effect of offender, legal and case characteristics. There are two key exceptions. First, the effect of the seriousness of current offending on the likelihood of an imprisonment order may be greater for non-Indigenous than Indigenous cases of violence, after adjusting for other known sentencing factors. Second, and importantly, the impact of the context of the violence is different for non-Indigenous and Indigenous cases of violence. Although being convicted of domestic violence had no meaningful or significant effect on the likelihood of imprisonment for Indigenous cases of violence, it significantly reduced the odds of imprisonment for non-Indigenous cases of violence. This suggests that the presence of domestic violence may be taken more seriously for Indigenous violent offenders, compared to non-Indigenous violent offenders.

\section{Summary and Discussion}

In part, reform in the criminal justice treatment of domestic violence (such as sentencing) has been motivated by the symbolism of harsher treatment of domestic violence offenders. For instance, if sentencing courts were to be equally punitive toward domestic and non-domestic 
violence, this provides an important symbolic statement to offenders, victims and the broader community that abuse between intimates and within families constitutes a significant public problem with great consequences to the community that must be addressed (Olso and Stalans, 2001: 1165-1166; Coker, 2001: 850-851). However, our analyses suggest that the symbolic message conveyed through increased punitivism is more likely delivered to Indigenous than non-Indigenous perpetrators of domestic violence. When sentenced under comparable statistical circumstances, Indigenous offenders who had perpetrated violence against intimates or family members were equally likely as other violent offenders to be sentenced to prison. In contrast, non-Indigenous domestic violence offenders were significantly less likely than those convicted of violent offences outside of these contexts to be sentenced to prison.

Broadly speaking, the focal concerns perspective suggests that societal expectations or concerns impact sentencing by partially shaping judicial assessments of blameworthiness and harm, risk, as well as practical constraints and consequences. These larger societal expectations and concerns may be different and changing for Indigenous and non-Indigenous domestic violence offenders. Post-Royal Commission into Aboriginal Deaths in Custody, courts did the work of sentencing Indigenous offenders in the context of: (a) high levels Indigenous over-representation in imprisonment needing to be reduced; (b) Indigenous offending occurring in an environment of relative high socio-economic disadvantage and high levels Indigenous community dysfunction; and (c) incarceration (in its own right) having a disproportionally high social cost to Indigenous offenders, families and communities. As suggested by sentencing precedence (and also prior sentencing disparities research), these concerns may have resulted in sentence severity being mitigated for Indigenous defendants at least in the higher and alternative courts (e.g. see Jeffries and Bond, 2009; Jeffries and Bond, 2010). 
However, more recently, as a result of numerous government taskforces, the problem and social cost of domestic violence in Indigenous communities has been thrust into the public domain. Arguably, the political and social environment has shifted for this type of offending, with domestic violence being construed as both a fundamental cause of Indigenous community dysfunction and a symptom of that dysfunction. At sentencing, therefore, judicial assessments of broader community harm, risk and cost may be aggravated by Indigeneity and lead to harsher sanctioning. This assumption is tentatively supported not only by our analyses but also, as discussed previously, by shifts in recent sentencing case law.

In contrast, to Indigenous domestic violence, non-Indigenous perpetrators of domestic violence have not evoked the same level of political and societal concern. Drawing on the focal concerns perspective, plausibly, non-Indigenous domestic violence may perceptually remain as somehow less harmful (than other forms of violence and Indigenous domestic violence), a private matter that poses little risk or cost to those outside immediate intimate or familial contexts. This may explain the differential treatment of non-Indigenous domestic violence compared to non-domestic violent crime. Thus, differences in broader societal concerns around domestic violence, which shape the ways magistrates perceive blame, risk and constraints, may explain the intersection between Indigeneity and the context of violence. As a result, the crimes of domestic violence by Indigenous offenders are potentially perceived as more blameworthy and risky within the context of their communities, than non-Indigenous domestic violence offenders.

Ironically, the push to take crimes of domestic violence seriously by treating offenders punitively is a concerning consequence of white feminist/domestic violence activism which 
sought, through the agents of the criminal justice system, to "harness state power as a counterbalance to patriarchal power in the private sphere” (Snider, 1998: 12). However, the use of the criminal justice system as a tool to change gendered and racial hierarchies of status and privilege is problematic. As argued by Martin (1998: 160), the courts are about order and its reproduction, and only incidentally about the safety of women, children and their communities. In other words, the courts do little to serve goals of equity and security, rather they dispense punishment and preserve white male state authority so that these existing power relations are legitimated and replicated (Martin, 1998: 155).

If punitiveness is not about providing solutions, then harsher sentencing in cases of domestic violence is unlikely to reduce the risk of future violence and harms to either Indigenous or non-Indigenous women and children (Hennnessy and Willie, 2006: 3). ${ }^{9}$ Nonetheless, as noted by Nancarrow (2006: 94-95), non-Indigenous victims of domestic violence still convey value in the court as mechanism for advancing the status of women. Incongruously, within the context of the current research but unsurprisingly given the 'whiteness' of the criminal justice system, Indigenous women see strategies of punitivness as another tool of racial oppression wielded against their communities (Nancarrow, 2006: 97; see also Goulding, 2007: 25; Cox, Young, Bairnsfather-Scott, 2009: 153). Taking domestic violence seriously in the context of Indigenous Australia through the increased use of incarceration separates and further fragments families and communities while simultaneously acting as a precursor to further violence (Nancarrow, 2006: 97; see also Goulding, 2007: 25; Cox, Young, BairnsfatherScott, 2009: 153). For example, Nancarrow (2006: 98) reports that Indigenous women

\footnotetext{
${ }^{9}$ Our discussion has been framed in terms of the safety of Indigenous women and children, but the proportion of Indigenous women (compared to non-Indigenous women) in our study raises the issue of the potential blurring of the distinction between victim and offender in Indigenous domestic violence. However, the proportion of Indigenous women recorded as having been convicted of domestic violence is lower (22.5\%) than that for nonIndigenous women (29.7\%). The broader issue of the intersection between gender and Indigeneity in the sentencing of violent offenders is important, and is being explored in a separate larger funded project.
} 
viewed the criminal justice system as responsible for escalating the abuse perpetrated against victims of domestic violence in two key ways. First, violence perpetrated within the criminal justice system against offenders including while incarcerated (e.g. rape and assault within prisons) often resulted in offenders returning to Indigenous communities more violent than when they left. Second, when Indigenous perpetrators of domestic violence were imprisoned this often led to retaliatory violence from the perpetrators' family toward the victim. The separation of families caused by incarceration was further seen as an extension of historical government policies of Indigenous familial separation, and not as a strategy of resolving the factors contributing to the violence (Nancarrow, 2006).

\section{Caveats and Directions for Future Research}

As in most sentencing studies, the conclusions drawn from the current research should be considered tentative. There are three key limitations. First, this is a study of the lower courts. Although the majority of domestic violence cases are processed at the lower court level, our findings may not generalise to higher court cases. Second, we have not been able to adjust for all contextual factors that may be known to the magistrate at sentencing, factors that may explain differences in the likelihood of imprisonment. For example, the extent of victim injury, use of weapon, the presence of children, and the nature (e.g. any past violence, type of past violence) of the offender's criminal history may all contribute to the assessments of blame and risk made by magistrates, which in turn, influence sentencing.

Finally, statistical analyses alone are unable to fully explore the process of judicial sentencing decision making (Daly, 1994; Jeffries and Bond, 2010, 2013). Although such an approach can establish whether or not Indigeneity intersects with the context of violence to impact sentencing, it cannot fully explain why this is the case. Future research needs to go beyond 
numerical examinations of court administrative databases to include qualitative analyses of information contained in court files and transcripts (such as judicial sentencing remarks, presentence reports), interviews with judges, as well as observational studies of the courtroom context. Such analyses would allow for a more in-depth examination of both Indigenous and non-Indigenous sentencing stories in domestic versus non-domestic cases of violence. Such approaches would lead to a better understanding how, at sentencing, judicial officers perceive Indigenous versus non-Indigenous perpetrators of domestic violence, and interpret Indigeneity in different relational contexts to rationalising their sentencing decisions.

\section{Acknowledgements}

We would like to sincerely thank the New South Wales Bureau of Crime Statistics and Research (BOSCAR) in providing access to the Reoffending Database (ROD). In particular, we acknowledge the support of Dr Don Weatherburn (Director, BOSCAR) and Jackie Fitzgerald (Deputy Director, BOSCAR). The views expressed in this paper do not necessarily reflect those of BOSCAR or any other New South Wales government agency.

\section{Funding}

This research received no specific grant from any external funding agency in the public, commercial, or not-for-profit sectors.

\section{References}

ABC News On-Line (2006) Courts Too Lenient on Aboriginal Domestic Violence: $D P P$. August $28^{\text {th }}$.

Anthony T (2010) Sentencing Indigenous offenders. Indigenous Clearinghouse Brief, 7. Canberra: Indigenous Clearinghouse. 
Anthony T (2013) Before the High Court Indigenising sentencing? Bugmy v The Queen. Sydney Law Review 35: 451-466.

Atkinson J (1990) Violence against Aboriginal Women: Reconstitution of community law - the way forward. Aboriginal Law Bulletin 46(2): 6-10.

Blagg H (2008) Crime, Aboriginality and the Decolonisation of Justice. Sydney: Hawkins Press.

Bolger A (1991) Aboriginal Women and Violence. Darwin: North Australia Research Unit (Australian National University).

Bond C and Jeffries S (2014) Similar punishment?: Comparing sentencing outcomes in domestic and non-domestic violence cases. British Journal of Criminology (in press).

Bond C and Jeffries S (2012a) Indigenous sentencing outcomes: A comparative analysis of the Nunga and magistrates Courts in South Australia. Flinders Law Journal 14(2): 359-382.

Bond C and Jeffries S (2012b) Indigeneity and the likelihood of imprisonment in Queensland's adult and children's courts. Psychiatry, Psychology and Law 19(2):169-183.

Bond C and Jeffries S (2011) Indigeneity and the judicial decision to imprison: A study of Western Australia’s higher courts. British Journal of Criminology 51(2): 256-277.

Busch R, Robertson N and Lapsley H (1995) The gap: Battered women’s experience of the justice system in New Zealand. Canadian Journal of Women and the Law 8(1):190222.

Coker D (2001) Crime, control and feminist law reform in domestic violence law: A critical review. Buffalo Criminal Law Review 4(2): 801-860. 
Crips K, Davis M and Taylor C (2008) Sexual violence in Aurukun The Queen v BP, DK, PA, Koowarta, Wikumena, Woolla 2007. Indigenous Law Bulletin 7(9): 14-17.

Cunneen C (1992) Judicial racism. Aboriginal Law Bulletin 44(2): 1-9.

Cox D, Young M and Bairnsfather-Scott A (2009) No justice without healing: Australian Aboriginal People and family violence. Australian Feminist Law Journal 30: 151161.

Commonwealth of Australia (1997) Bringing Them Home: Report of the National Inquiry Into the Separation of Aboriginal and Torres Strait Islander Children From Their Families. Sydney: Human Rights and Equal Opportunities Commission.

Douglas H (2005) She knew what was expected of her: The white legal system's encounter with traditional marriage. Feminist Legal Studies, 13(2): 181-203.

Dawson, M (2004) Rethinking the Boundaries of Intimacy at the End of the Century: The Role of Victim-Defendant Relationship in Criminal Justice Decision Making Over Time. Law and Society Review 38(1): 105-138.

Douglas H and Corrin J (2010) 'A tragedy of monumental proportions’: Indigenous Australians and the sentencing process. Social and Legal Studies 19(2): 197-215.

Du Mont, J, Parnis, D and Forte, T (2006) Judicial Sentencing in Canadian Intimate Partner Sexual Assault Cases. Medicine and Law 25(1): 139-157.

Fradella H.F and Fischer R.G. (2010) Factors impacting sentence severity of intimate partner violence offenders and justification for the types of sentencing imposed by mock jurors. Law and Psychology Review 34:25-53.

Gilchrist E and Blissett J (2002) Magistrates' attitudes to domestic violence and sentencing options. The Howard Journal 41(4): 348-363. 
Gordon S, Hallahan K and Henry D (2002) Putting the Picture Together, Inquiry into Response by Government Agencies to Complaints of Family Violence and Child Abuse in Aboriginal Communities. Perth: Western Australian Government.

Goulding D (2007) The Role of Socio-Economic and Familial Factors in the Pursuit of Final Violence Restraining Orders For Women Subjected to Family and Domestic Violence. Perth: Murdoch University Research Centre for Social and Community Research.

Hartman J L and Belknap J (2003) Beyond the gatekeepers: Court professionals’ selfreported attitudes about and experiences with misdemeanor domestic violence cases. Criminal Justice and Behavior 30(3): 349-373.

Hennessy A and Willie C (2006) Sentencing Indigenous offenders in domestic and family violence matters: A Queensland experience. Paper Presented at the Australia and New Zealand Society of Criminology 2006 Conference, Criminology and Human Rights Hobart 79 February.

Hessick C B (2007) Violence between lovers, strangers and friends. Washington Law Review 85: 344-402.

Jarrett S (2013) Liberating Aboriginal Peoples from Violence. Ballan: Connor Court Publishing.

Jeffries S and Bond C (2013) Does court context matter?: The likelihood of imprisonment for Indigenous and non-Indigenous offenders sentenced in problem-solving courts. International Journal of Law, Crime and Justice 41(1): 100-114.

Jeffries S and Bond C (2012) Indigenous disparity in lower court imprisonment decisions: A study of two Australian jurisdictions 1998-2008. Trends and Issues in Criminal Justice, 447. Canberra: Australian Institute of Criminology. 
Jeffries S and Bond C (2011) The sentencing of offenders in the lower courts: A study of three Australian jurisdictions. Canberra: Criminology Research Council.

Jeffries S and Bond C (2011) Indigeneity and the Decision to Impose a Fine in Queensland's Magistrates Courts. In Threadgold S, Kirby E and Germov, J (eds). Local Lives/Global Networds: Proceedings of the Annual Conference of The Australian Sociological Association 2011. Newcastle: TASA.

Jeffries S and Bond C (2009) Does Indigeneity matter?: Sentencing Indigenous offenders in South Australia's higher courts. Australian and New Zealand Journal of Criminology 42(1): 47-71.

Jeffries S and Bond C (2010) Narratives of mitigation: Sentencing Indigenous criminal defendants in South Australia’s higher courts. Journal of Sociology 46(3): 219-237.

Jeffries S, Fletcher G and Newbold G (2003). Pathways to sex-based differentiation in criminal court sentencing. Criminology, 41(2): 329-353.

Johnson B.D (2003) Racial and ethnic disparities in sentencing departures across modes of conviction. Criminology 41(2): 449-489.

Marchetti E (2011) Culture versus gender: How the mainstream criminal court system is still getting it wrong. Indigenous Law Bulletin 7(26): 27-30.

Martin D L (1998) Retribution revisited: A reconsideration of feminist criminal law reform stratigies. Osgoode Hall Law Journal 36(1): 151-188.

McCormick J S, Maric A, Seto M C and Barbaree H E (1998) Relationship to victim predicts sentence length in sexual assault cases. Journal of Interpersonal Violence 13(3): 413-420. 
McGlade H (2013) Aboriginal sentencing punishes the victims. The Australian, August $2^{\text {nd }}$.

Menard S (2002) Applied Logistic Regression Analysis, $2^{\text {nd }}$ ed. Thousand Oaks, CA: Sage.

Mitchell O (2005) A meta-analysis of race and sentencing research: Explaining the inconsistencies. Journal of Quantitative Criminology 21(4): 439-466.

Nancarrow H (2006) In search of justice for domestic and family violence: Indigenous and non-Indigenous Australian women's perspectives. Theoretical Criminology 10(1): 87106.

New South Wales Attorney Generals Department (2006) Breaking the Silence, Creating the Future: Addressing Child Sexual Assault in Aboriginal communities in NSW / NSW Aboriginal Child Sexual Assault Taskforce. Sydney: New South Wales Attorney Generals Department.

Northern Territory Government (2007) Ampe Akelyernemane Meke Mekarle "Little Children are Sacred": Report of the Northern Territory Board of Inquiry into the Protection of Aboriginal Children from Sexual Abuse. Darwin: Northern Territory Government.

Ogilvie E (2000) Stalking: Legislative, Policing and Prosecution Patterns in Australia. Canberra: Australian Institute of Criminology.

Olso D E and Stalans L J (2001) Violent offenders on probation: Profile, sentence, and outcome differences among domestic violence and other violent probationers. Violence Against Women 7(10): 1164-1185. 
Payne S (1992) Aboriginal women and the law. In: Cunneen C (ed) Aboriginal Perspectives on Criminal Justice. Sydney: Sydney University Institute of Criminology.

Ptacek J (1999) Battered Women in the Court Room. Boston: Northeastern University Press.

Ringland C and Fitzgerald J (2010) Factors which Influence the Sentencing of Domestic Violence Offenders. Sydney: New South Wales Bureau of Crime Statistics and Research.

Robinson N (2013) Disparity in black sentences ‘perverse’ says Mick Goodna. The Australian, January $10^{\text {th }}$.

Royal Commission into Aboriginal Deaths in Custody 1991 National Report. Canberra: Federal Government.

Snider L (1998) Towards safer societies: Punishment, masculinities and violence against women. The British Journal of Criminology 38(1): 1-39.

Southwood S (2007) Equality of the law and the sentencing of Aboriginal offenders under the Sentencing Act (NT). Paper presented to Rule of Law: The Challenges of a Changing World Defending and Preserving the Rule of Law in a Climate of Global and Regional Uncertainty Symposium, Brisbane, 31 August - 1 September 2007.

State of Queensland (1999) The Aboriginal and Torres Strait Islander Women's Task Force on Violence Report. Brisbane: State of Queensland.

State of Victoria (2003) Victorian Indigenous Family Violence Task Force: Final Report. Melbourne: Victorian Government. 
Steffensmeier D and Demuth S (2006) Does gender modify the effects of raceethnicity on criminal sanctions? Sentences for male, female, white, black and Hispanic defendants. Journal of Quantitative Criminology 22(3): 763-797.

Steffensmeier D, Ulmer J and Kramer J (1998) The interaction of race, gender, and age in criminal sentencing: The punishment cost of being young, black and male. Criminology 36(4): 763-798.

Snowball L and Weatherburn D (2007) Does racial bias in sentencing contribute to Indigenous overrepresentation in prison? Australian and New Journal of Criminology 40(3): 272-290.

The Royal Commission into Aboriginal Deaths in Custody (1991) National Report. Canberra: Federal Government.

\section{Legislation}

Crimes (Domestic and Personal Violence) Act 2007 (New South Wales) 
Table 1. Description of study variables, New South Wales lower courts, violent offences

(January 2009- June 2012)

\begin{tabular}{ll}
\hline Variables & Description \\
\hline Dependent variable & $0=$ no, not sentenced to prison; $1=y e s$, sentenced to prison. \\
Sentence of incarceration order & \\
Independent variables & At time of sentencing (in years). \\
Offender social characteristics & $0=$ mail; $1=$ female \\
Age & $0=$ non-Indigenous; $1=$ Indigenous. Indigenous status is based on self- \\
Sex & identification by the defendant.
\end{tabular}

Legal and case characteristics

Prior appearances

Ordinal measure of number of all prior proven criminal court appearances in the last 10 years from current case. $0=0$ to 1 prior appearance; $1=2-4$ prior appearances; $2=5$ or more prior appearances.

Seriousness of principal offence Reverse coded National Offence Index (NOI).

Convicted of multiple counts $0=$ no; 1 =yes.

Released pre-trial $0=$ no; 1 =yes. Refers to whether out of custody at the time of finalisation of the case.

Mode of conviction

$0=$ no trial; $1=$ trial

Domestic violence offence $0=$ no, not convicted under domestic violence provisions; 1=yes, convicted under domestic violence provisions

Source: ROD database (NSW Bureau of Crime Research and Statistics) 
Table 2. Descriptive statistics of study variables, New South Wales lower courts, violent offences (January 2009- June 2012, N=58,664)

\begin{tabular}{|c|c|c|c|c|}
\hline & Total cases & Indigenous cases & $\begin{array}{c}\text { Non-Indigenous } \\
\text { cases }\end{array}$ & Difference \\
\hline \multicolumn{5}{|l|}{ Social history characteristics } \\
\hline \% Indigenous & 19.24 & --- & --- & \\
\hline$\%$ female & 17.93 & 24.39 & 16.39 & $* * *$ \\
\hline Mean age at disposition (in yrs) & $33.35(11.52)$ & $31.37(9.81)$ & $33.83(11.84)$ & $* * *$ \\
\hline \multicolumn{5}{|l|}{ Legal and case characteristics } \\
\hline Median number of prior appearances & 2 & 5 & 2 & $* * *$ \\
\hline Mean seriousness score of current offence & $127.60(5.85)$ & $128.26(5.41)$ & $127.45(5.93)$ & $* * *$ \\
\hline \% with multiple conviction counts & 47.19 & 59.26 & 44.31 & $* * *$ \\
\hline$\%$ released pre-trial & 88.69 & 74.29 & 92.12 & $* * *$ \\
\hline \% went to trial & 13.48 & 13.16 & 13.55 & n.s. \\
\hline$\%$ with specific domestic violence charge & 29.27 & 27.80 & 29.62 & $* * *$ \\
\hline \multicolumn{5}{|l|}{ Sentence outcome } \\
\hline \% with a prison sentence & 11.18 & 25.63 & 7.74 & $* * *$ \\
\hline Total number of cases & 58,664 & 11,287 & 47,377 & \\
\hline
\end{tabular}

Source: ROD database (New South Wales Bureau of Crime Research and Statistics)

$\# \mathrm{p}<0.10{ }^{*} \mathrm{p}<0.05{ }^{* *} \mathrm{p}<0.01{ }^{* * *} \mathrm{p}<0.001$

Notes:

1. Means (with standard deviations in brackets) are reported for continuous variables; percentages are reported for dichotomous variables.

2. T-tests for difference between group means, and z-test for difference between group proportions, are used to test whether there is a significant difference between domestic violence and non-Indigenous cases. Wilcoxon rank-sum test was used to evaluate differences in rank ordering between Indigenous and non-Indigenous cases.

3. Median: age (32); seriousness score (128). The Wilcoxon rank-sum test confirms that there is a statistically significant difference in the ranking order in offence seriousness and in age between Indigenous and nonIndigenous cases. 
Table 3. Model of Imprisonment Order on Key Offender and Case Characteristics, Violence Offences, New South Wales lower courts $(N=58,664)$

\begin{tabular}{|c|c|c|c|c|c|c|}
\hline & \multicolumn{3}{|c|}{ Indigenous cases } & \multicolumn{3}{|c|}{ Non-Indigenous cases } \\
\hline & Coeff. & s.e. & O.R. & Coeff. & s.e. & O.R. \\
\hline \multicolumn{7}{|l|}{ Offender characteristics } \\
\hline Female & $-0.791^{* * *}$ & 0.093 & 0.453 & $-0.884^{* * *}$ & 0.096 & 0.413 \\
\hline Age at disposition & 0.005 & 0.004 & 1.005 & $0.005^{*}$ & 0.002 & 1.005 \\
\hline \multicolumn{7}{|l|}{ Legal and Case characteristics } \\
\hline 2-4 (vs 0-1) prior appearances & $0.514^{* *}$ & 0.189 & 1.671 & $0.709^{* * *}$ & 0.073 & 2.033 \\
\hline 5 or more (vs $0-1$ ) prior appearances & $1.589^{* * *}$ & 0.181 & 4.899 & $1.697^{* * *}$ & 0.073 & 5.459 \\
\hline Seriousness principal offence & $0.057^{* * *}$ & 0.007 & 1.059 & $0.081^{* \% * \%}$ & 0.004 & 1.084 \\
\hline Multiple conviction counts & $0.706^{* * *}$ & 0.071 & 2.025 & $0.726^{* * *}$ & 0.052 & 2.067 \\
\hline Released pre-trial & $-3.621^{* * *}$ & 0.067 & 0.027 & $-3.753^{* * *}$ & 0.051 & 0.023 \\
\hline Trial & $0.287^{* *}$ & 0.095 & 1.333 & $0.334^{* * *}$ & 0.065 & 1.397 \\
\hline Domestic violence offence & -0.038 & 0.076 & 0.963 & -0.471 & 0.057 & 0.624 \\
\hline Constant & $-7.934^{* * *}$ & 0.953 & & -11.414 & 0.583 & \\
\hline Psuedo $\mathrm{R}^{2}$ & & 0.490 & & & .468 & \\
\hline $\mathrm{N}$ & & 1,287 & & & 7,377 & \\
\hline
\end{tabular}

Source: ROD database (New South Wales Bureau of Crime Research and Statistics)

$\# \mathrm{p}<0.10 ;{ }^{*} \mathrm{p}<0.05 ; * * \mathrm{p}<0.01 ; * * * \mathrm{p}<0.001$

Notes:

1. Robust standard errors are provided to take account of the clustering due to repeat appearances of the same offender on new matters. There were 9,411 and 2,396 (respectively) clusters of repeat defendants in the Indigenous cases model, and 43,716 and 3,301 (respectively) in the non-Indigenous cases model. Fit statistics are based on the unclustered model for technical reasons.

2. The area under the ROC curve is 0.92 and $\chi^{2}=6296.82$ (d.f. $=10 ; \mathrm{p}<0.001$ ) (Indigenous model) and 0.92 and $\chi^{2}=12086.32$ (d.f. $=10 ; \mathrm{p}<0.001$ ) (Non-Indigenous model).

3. To test whether the estimated coefficients between the Indigenous and non-Indigenous models were significantly different, a combined model with interaction effects was used. Shaded boxes were statistically significantly different at the 0.05 level. 